\title{
Three Decades of Public Expenditure Management in Zimbabwe
}

\author{
Gideon Zhou \\ Dept. of Politics and Administration, University of Zimbabwe \\ PO Box MP 167, Mt Pleasant, Harare, Zimbabwe \\ Tel: +263-4-303211Ｅ-mail: gideonzhou62@ gmail.com
}

Received: June 22, 2012 Accepted: July 21, 2012 DOI: 10.5296/jpag.v2i3.2098

\begin{abstract}
Sound public expenditure management forms the bedrock of public administration. It facilitates prudence, efficiency, transparency and accountability in expenditure processes at various levels of government. This serves as a long term barricade against debt trap. This article responds to these fundamental concerns by examining the nature, processes and challenges of public expenditure management in Zimbabwe. Reviews of expenditure management systems in Zimbabwe show general consistence with those in Anglophone Africa. Ministries of finance, working closely with spending ministries, Accounting Officers, Public Accounts Committees of Parliament, Auditor Generals and internal auditors-constitute key players in the public expenditure management process. Notwithstanding this, overall expenditure over the decades remained sticky downwards due to inflationary pressures, unbudgeted expenditures and weak expenditure management systems. Robust measures should be put to institutionalize a culture of compliance with extant expenditure management frameworks at both the macro and micro levels of government.
\end{abstract}

Keywords: public expenditure management, ministries of finance, spending ministries, Accounting Officers, Public Accounts Committees 


\section{Introduction}

Robust expenditure control systems lay the foundation for effective public administration. They facilitate discipline, efficiency, transparency, accountability in the use of fiscal resources within the various structures of government (OECD, 1998; African Development Bank Institute, 2000). In fact, effective expenditure management systems serve as long term barricades against corruption, fiscal leakage and the risk of debt trap. World Bank (2001) posits a link between effective public spending management and poverty reduction while Isikawa (2006) presents expenditure management as integral components of fiscal reforms. The debt crises currently dogging Africa governments are largely linked to inept expenditure management systems and practices (ZIMCODD, 2001; World Bank, 1998; Shaw, 2005, AFRODAD, 2011; IMF, 2011).

Cursory review of the fiscal situation in Zimbabwe presents a particularly compelling case for institutionalizing robust expenditure management systems and practices. Zimbabwe currently has a total debt stock of around US\$10 billion. National efforts directed towards reopening external lines of credit and expanding domestic revenue inflows have not been yielding much since the formation of the inclusive government. Review budget statements suggest that the ministry of finance (treasury) is partially in control of national revenue collection processes (GoZ Budget Statement, 2012, Zhou, 2012).

Public expenditure management is a long term process in which fiscal authorities and managers undertake periodic reviews of their spending decisions and activities in a bid to reduce costs stemming from unnecessary spending, unbudgeted expenditures, fiscal indiscipline, corruption and lack of transparency and accountability. The sphere of public expenditure management involves planning and budgeting of national expenditures, auditing of expenditures, cash and debt management and strengthening of treasury and parliamentary controls, among other (Musgrave \& Musgrave, 1984; Mikesell, 2011; OECD, 2003). These expenditure control measures are enforced within specific institutional, legal and policy frameworks. Prior appreciation of these frameworks is therefore critical in analyzing the dynamics of public expenditure management in any country.

\section{Components of Public Expenditure}

Public expenditures are costs incurred by central, state and local institutions of government. Public expenditures are essentially government expenditures covering outlays on political executives (heads of states), administrative expenditures, security expenditures, expenditures on administration of justice, development expenditures, debt payments (Dalton, 1970, 175). Government expenditures are generally classified as 'capital' and 'current', the latter being non-recurring costs arising from creating the socioeconomic infrastructure in the form of roads, bridges, power generation, agricultural production, industrial expansion, communication infrastructure, among others. Current expenditures are non-investment, exhaustive and recurrent in nature and as such hardly create productive assets which generate returns to government-hence their categorization as 'consumption' and 'transfer' expenditures (Aronson, 1985; Visser and Erasmus, 2005). Consumption expenditures relate to the day to 
day expenses of governments in the form of administration, maintenance, employment and debt-related costs while transfer expenditures are costs in the form of subsidies, educational grants, state pensions, social benefits and War Veterans Gratuities, unemployment benefits, sickness benefits and old-age pensions (Groves, 1955; Musgrave and Musgrave, 1984; UNDP/IDS/Poverty Reduction Forum, 2003, 8). Transfers are payments for which no goods or services are exchanged (http://www.bized,co.uk). It is however instructive to note that while transfer expenditures do not generate direct financial returns to government, they are nevertheless significant in that they promote public welfare by redistributing income within society(African Development Bank Institute, 2000; IMF 2011).

Current expenditures are also classified as 'discretionary' and 'non-discretionary', the latter being costs covering wages, interest payments and constitutional and statutory obligations that are permanently appropriated by law (Prest, 1968; Hayman, 1990; Aronson, 1985, 7). Prior appreciation of these expenditure components is critical in establishing areas where expenditure control interventions should be prioritized. Without this correct delineation of the expenditure profile, control efforts risk being a will-of-the-wisp chase. It is also important to appreciate that public expenditures are inevitable because governments have sovereign duties to provide basic goods and services to their citizens. Public goods are non-rival and in-excludable, characteristics that render them less amenable to provision by private players. Once provided, they become available to everyone at zero costs (see Bailey, 1995; Musgrave and Musgrave, 1984; Buchanan, 1998).

\section{Key Considerations in Public Expenditure Management}

A central issue in public expenditure management concerns the judicious allocation of government expenditures. How aggregate expenditure has far reaching implications for national socioeconomic growth and development. Effective public expenditure management should therefore question spending decisions at both the macro and micro levels of government.

\subsection{Macro Level Issues}

Macro level expenditure management analysis is aggregative and accordingly questions the share of aggregate expenditure in Gross Domestic Product (GDP). GDP measures the total final outputs of goods and services produced by the country's economy, that is, those produced within the country's territory by residents and non-residents (Fox \& Meyer, 1995; Musgrave \& Musgrave, p: 23). Analysis of aggregate expenditure in GPD therefore helps fiscal authorities to determine how much of aggregate national income is consumed by aggregate public expenditure. Fiscal literature generally counsels that aggregate public expenditures should not consume half of the total national revenue (IMF, 2011; Fjeldstad and Moore, 2008; ZIMCODD, 2001, Shaw, 2005; Schiller, 2003). Prudent expenditure management demands that fiscal planners take concerted effort to ensure that the share of aggregate public expenditure in GDP remains at levels that are sustainable by the national revenue reserve economy. 
It should also interrogate the nature of Vote allocations, ranking them in terms of funding. Votes are ministerial allocations placed under the management of Accounting Officers who are Heads of line ministries (spending ministries). Analysis of Vote appropriations over a stretch of time helps to establish sectors that were prioritized by government. Analysis of Vote allocations is in essence an examination of the spending decisions of government. Core guiding questions should be: How have aggregate expenditures been allocated to various sectors of government over the years? Which ministries/sectors have consistently received the largest funding? What accounts for their prioritization? Are Vote allocations developmental?

Equally critical is to analyze the share of 'capital' and 'current' expenditures in aggregate expenditure. Capital expenditures cover costs in social and economic infrastructure development. In most national budgets, capital expenditures are animated by the Public Sector Investment Programme (PSIP). Current expenditures as discussed above are the day to day costs for administration, maintenance services, salaries, pensions, transfers etc. Both are critical as a health expenditure allocation to the social sector promotes human capital (services such as health, education and training) which is a critical ingredient in capital formation and wealth creation. While the issue of what expenditure category should be prioritized is a long standing one (Hassa \& Jajri, 2011; Ahmed \& Miller, 2000; Bahram \& Frank, 1998), classical economic arguments generally present capital expenditure as productive and essential investment which lays the basis for future revenue generation and economic growth (Smith, 1937; Eshaq, 1983; Aschauer. 1989 and Odedukun, 1997, IMF, 2011).

Public expenditure management also entails examining the share of 'defense' and 'civilian' spending in aggregate expenditure, the guns versus butter debate (Tobin, 1980). Civilian expenditures are expenditure allocations to social sector ministries and departments of education, health and social welfare. Researches opposed to increased defense spending generally argue that that constitute a drain on resources that should be available for economic and social development (Woods, 2011; Looney, 1988, Smith, 1937), Smith describing them as an unproductive expenditure that detracts from the wealth of nations. A health per capita allocation to the civilian sectors is said to be a sine qua for improving citizen socioeconomic welfare. In peaceful times, society expects a significantly reduced military spending, the logic being that it will result in increased expenditure allocations to AIDS/HIV victims (UNDP/IDS/Poverty Reduction Forum, 2003). Although according to Brzoska Michael by 2004 global spending on military was around US\$85 billion compared to civilian spending of US $\$ 850$ billion, it is instructive to note that ratios between military and civilian spending varies widely among countries. In the 2004 global military spending of US $\$ 85$ billion, 60 percent was accounted for by the USA (http://www.ifsh.de/pdf/aktuelles/india-brzoska.pdf).

Debt servicing has become one of the most visible expenditure items in the national budgets of developing countries, draining limited budgetary resources that should otherwise be used for human development and poverty reduction (ZIMCODD, 2001; Levine \& Rubin, 1980; IMF, 2002; OECD, 2003). It generates far reaching negative externalities on present and future generations. Public expenditure management should also be concerned with the share 
of national debt-serving expenditures in total national expenditure. In Zimbabwe, the need to analyze the issue of debt servicing is even more pressing given that most critical sectors of the economy are yet to get back to full production levels (Government of Zimbabwe, Budget Statement, 2012). The economic recovery drive can hardly make progress if the debt overhang challenges are not resolved. At the end of December 2010, Zimbabwe's unvalidated external debt position was estimated at US\$6.9 billion (103 percent of GDP), of which US $\$ 4.8$ billion (72 percent of GDP) are accumulated arrears (GoZ, Accelerated Arrears Clearance, Debt and Development Strategy, 2012, p: 4).

\subsection{Micro Level Analysis}

Micro level analysis has the ministry as its unit of analysis. It dissects the ministerial Vote in order to establish how it is distributed among competing programmes and projects within the ministry. This in turn helps to establish the feasibility and sustainability of ministerial prioritizations. For example, in analyzing the Vote to the ministry of Health and Child Welfare, concern should be with how expenditures are distributed between 'curative' and 'preventive' heads of expenditures. Ministerial Vote analysis should also establish why certain expenditure heads and sub-heads are prioritized. This helps to flush out 'dead wood' projects, projects that would have outlived their usefulness but continue to receive budgetary support. Thus besides enhancing transparency at ministerial level, micro expenditure analysis ensures that expenditures are allocated to needy projects, which in turn improves institutional service delivery.

\section{Public Expenditure Management Controls}

\subsection{Legal Controls}

The roots of public expenditure management in Zimbabwe lie in Sections 102, 103 and 105 of the Constitution which govern issues of withdrawals and payments into the Consolidated Revenue Fund (CRF) by providing that "no moneys shall be withdrawn from the CRF except to meet expenditures that are charged upon by the constitution or by an Act of Parliament". Section 105 of the Constitution provides for additional controls on public expenditure by authorizing the Office of the Comptroller and Auditor General to act as watchdog on matters dealing with public funds by auditing the accounts of all government ministries, departments and public enterprises. The detailed regulatory framework on the management of public expenditures is provided in the Public Finance Management Act (Chapter 22:19) and the Audit Office Act (Chapter 22:18). The Appropriation Act provides additional expenditure controls by authorizing the disbursement of Votes.

\subsection{Treasury Controls}

Public expenditure management is also enforced through specific institutions which are directly involved in monitoring, planning, coordinating, supervising and controlling of expenditure processes at the macro and micro levels of government. The ministry of finance (the Treasury) is constitutionally and statutorily mandated to ensure expenditure restraint 
within government institutions. The ministry of finance is authorized to issue instructions and directions to government officers to guide them in matters relating to collection, receipt, custody, control and issue of expenditure of public moneys. Within ministries of finance are specific departments and units that are directly responsible for coordinating and supervising matters relating to expenditure. The ministry finance also enforces expenditure control through the budget. By preparing national budgets, ministries of finance determine expenditure allocations to all government departments as well as instilling fiscal discipline by formulating policy measures to restrain expenditure in line ministries. Ministries of finance are also mandated to ensure that line ministries submit quarterly and annually expenditure reports. These activities enable ministries of finance to keep track of expenditure transactions within government ministries and state bodies.

Within each ministry are internal auditors who inspect the books of accounts of the various cost centers to establish if the funds are being used for their intended purposes. In cases of anomalies, these are brought to the attention of Accounting Officers for redress. However, their effectiveness as internal auditors may be compromised by lack of cooperation from other actors. It should also be noted that as junior officers, auditing the spending decisions of their ministries amounts to auditing the decisions of the Head of ministry. It may be difficult to ask the Permanent Secretary to enforce their observations when he/she is at fault.

\subsection{Controls by Accounting Officers (AOs)}

Permanent Secretaries (as Heads of ministries) are integral components of the national expenditure management systems. They serve as Chief Accounting Officers in ministries, exercising special responsibility to Parliament in as far as public funds under their charge are concerned (Goel, 1995). In Zimbabwe, each ministry has a Permanent Secretary as its Chief Accounting Officer. In fact, the Office of the Chief Accounting Officer is one of the three public institutions that assist the Parliament in its day to day financial controls of public funds. The Accounting Officer is expected to provide estimates of expenditure or other information to Treasury and Parliament from time to time as required. However, since a minister is a political appointee, the Accounting Officer is always subjected to striking a balance between political and professional considerations.

\subsection{Controls by Procurement Committees}

Expenditure management is also enforced through procurement committees which are set up in each line ministry to ensure that all purchases are done transparently and guided by set criteria. Procurement committees operate on the basis of the Three Quotations Rule that requires the submission of three quotations before a decision on where to make purchases can be made. The Committee is thus forced to compare prices and make a decision on the merit of the companies that will have provided the quotations. Effectiveness of these frameworks is usually compromised by insider trading and lack of transparency (Zhou, 2011). 


\subsection{Budgetary Controls}

Across the world, national budgets serve as central instruments of fiscal management. The lengthy and consultative budgetary processes provide inbuilt mechanisms of expenditure control. Within yearly national budgets are expenditure restraint measures that are taken in order to align expenditure within budget limits. Review of national budgets in Zimbabwe since 1980 point to protracted efforts towards instilling expenditure restraint within government departments and exhortations for zero tolerance to supplementary budgets. This intolerance was visibly manifest in the 2005 national budget where the then minister of finance (Herbert Murerwa) urged zero tolerance to supplementary budgeting and a restriction of unbudgeted expenses to national emergencies (GoZ, Budget Statement, 2005). Expenditure control was also reinforced through target-based-cash-flow management systems which required all ministries to operate or live within their Vote allocations. Theses exhortations are also need echoed in all national budget statements crafted under the inclusive government generally running under the fiscal theme "we eat what we kill" (GoZ, Budget Statements, 2010, 2011 and 2012).

\subsection{Public Finance Management System}

Public expenditure management is also enforced through a Public Finance Management System (PFMS) that was adopted in 1999 and centrally coordinated through the Central Computing Services in the ministry of Finance. Its adoption meant a shift from the Central Payments Office. As a computerized system, PFMS ensures that individual ministries manage their expenditures effectively, efficiently and economically. The system enhances expenditure restraint by making it a requirement that line ministries (spending ministries) submit expenditure reports to the Ministry of Finance before any funds applied for are released. Its performance since introduction has been encouraging. However effectiveness of PFMS has been affected by constant electricity blackouts, the hyperinflationary conditions between 2002 and 2008 which saw expenditure going up to quintillions.

The adoption of Government Finance Statistics (GFS) in 2004 also strengthened public expenditure management framework as the system enables continuous tracking of expenditure whilst fostering allocative efficiency and effective utilization of public resources (GoZ, National Budget Statement, 2004). Government Finance Statistics is an integral component of expenditure management in Zimbabwe.

\subsection{Parliamentary controls}

Across the world, legislative arms constitute integral elements national expenditure control systems by ensuring that expenditures are allocated only for purposes approved by parliament. They authorize yearly expenditures by passing enabling legislation such as Appropriation Bills which specify the funds which ministries are authorized to spend in a given fiscal year. By passing enabling legislation, parliaments give authority to the ministry of finance to disburse funds to line ministries. Parliaments also exercise expenditure through oversight functions-monitoring public expenditure activities through formal control mechanisms of 
reporting, inspection, statistical returns, cost accounting and analysis ratification and authorization, keeping of daily files, auditing of accounts, authorization and administration. Parliaments also monitor expenditure activities of government ministries through their permanent and ad-hoc committees. For instance, through Public Accounts Committees, parliaments ensure that legislative grants for each year are applied for their intended purposes. In the event of reported cases of wastefulness and unnecessary expenditures in some ministries, permanent secretaries as Chief Accounting Officers of their ministries, can be called upon to appear before Public Accounts Committees to account for adverse reports of their ministries. However, the main drawback is that parliamentary committees do not have power to ensure that their observations and recommendations are complied with. The setting up of portfolio committees to shadow the activities of all government ministries in Zimbabwe has since 1996 strengthened parliamentary oversight by enabling timely interventions in curbing wasteful expenditures. Parliamentary scrutiny has also been strengthened by its active involvement in pre-and post-budget activities.

\section{Public Expenditure Trends}

\subsection{The First Decade (1980-1990)}

Analysis of expenditure trends in post independence Zimbabwe presents an interesting case study of the impact of local and global dynamics impact on expenditure management. In the first ten years of independence, nation building imperatives involving the reconstruction of the socioeconomic infrastructure and the need to expand service delivery by government to all hitherto neglected segments of society accounted for the adoption of expansionary fiscal policies (Seidman, 1986; Bond, 1998). The education sector experienced expansions in enrolments from primary to tertiary level (Zvobgo, 1987). In the health sector, new health centers were established across the country, existing ones undergoing major restructuring and general expansion. Real per capita spending in the health sector increased from Z\$37 in 1983 to Z\$49 by 1989 (Loewenson and Chisvo, 1994; UNDP/Poverty Reduction Forum, 1999). Refer to the table below:

Table 1: Expenditure on Health

\begin{tabular}{|l|lr|l|l|}
\hline Financial Year & $\begin{array}{l}\text { Total } \\
\text { Expenditure peal } \\
\text { Capital }\end{array}$ & $\begin{array}{l}\text { Health Expenditure } \\
\text { as \% of GDP }\end{array}$ & $\begin{array}{l}\text { Health Expenditure } \\
\text { as of Total } \\
\text { Government } \\
\text { Expenditure }\end{array}$ \\
\hline $1980 / 81$ & 35.62 & 2.0 & 5.3 \\
\hline $1983 / 84$ & 36.74 & 2.2 & 4.8 \\
\hline
\end{tabular}




\begin{tabular}{|l|l|l|l|}
\hline $1985 / 86$ & 39.48 & 2.5 & 5.3 \\
\hline $1988 / 89$ & 44.82 & 2.6 & 5.3 \\
\hline
\end{tabular}

Source: UNDP/Poverty Reduction Forum, 1999, p: 9

Transfer expenditures in the form of subsidies constituted a very visible component of the first decade fiscal policy. In the 1981/82 financial year, subsidies constituted $11.6 \%$ of total government expenditure with subsidies to Agricultural Marketing Boards constituting the bulk of subsidy expenditures. Subsidies were meant to hold down prices of basic food varieties while ensuring a huge return to producers. By 1990 subsidies constituted 10 percent of GDP while the public service workforce had risen to 192000 from its 1980 level of 45000 (GoZ A Framework for Economic Reform, 1991, 4). This increase in public service workforce meant an increase in the public service salary and wage bill.

Inflationary pressures also pushed up the costs of local inputs while the fall in the value of local currency pushed up import costs on agro-industrial equipment and fuel. Chronic drought-spells in 1982, 1984-85, 1992, 2000, 2003, and 2005, in turn, forced the government to import maize using scarce foreign resources, thus worsening the import bill (Rukuni \& Eicher, 1994; Mumbengegwi, 1987).

Political and security factors also had a significant impact on public expenditure growth in Zimbabwe. Political instability forced the government to provide security to the Beira Corridor, the transportation link with Zimbabwe through Mozambique (ZIMCODD, 2001). By the close of the first decade, the total costs arising from forces of destabilization had risen to US\$8 billion (Ibid: 21). The cumulative effect of these factors was the rise in aggregate expenditure from its 1979/80 level of Z\$1 057 million to Z\$10 959 million by end of 1992 (UNDP/IDS/Poverty Reduction Forum, 2003, 54).

\subsection{The Second Decade (1991-1999)}

The adoption of ESAP ushered in a public expenditure management dispensation characterized by substantial reductions in social sector spending, elimination of subsidies to public enterprises and reduction in the size of the civil service wage bill. cost saving and drastic cuts in social sector expenditures (GoZ Framework for Economic Reform, 1991; Peters and Savoie, 1994; IMF, 2011). This was enforced through an array of measures that included, declaring certain posts redundant, encouraging civil servants to go for early retirement, freezing promotions and salary increases (Agere, 1993). However, the net impact of these austerity measures on reducing overall expenditure remains debatable. The budget deficit which in 1997 had dropped to 6.4 percent of GDP had by 1999 risen to 9 percent of GDP (Mlambo, 1990; Zhou, 2001; UNDP/Poverty Reduction Forum, 1999, 8). 


\section{Macrothink

Overall expenditure remained sticky downwards as expenditure outturns frequently surpassed expenditure targets, making supplementary budget a major post budget feature (UNDP/Poverty Reduction Forum, 1999, 6). Actual total expenditure which stood at Z\$1 057 million at the end of 1979/80 fiscal year had by the end of 1992 risen to Z\$10 959 million, increasing further to Z\$342.5 billion by 1999 (UNDP/IDS/Poverty Reduction Forum, 2003, 54).

Expenditure allocations remained heavily skewed against capital expenditure (see Table 2 below). However, the current expenditure component showed a disproportionately large share of non-discretionary expenditures such as employment costs (salaries, wages, pensions and allowances), interest payments and other constitutional and statutory obligations that are appropriated by law. Further dissection of the non-discretional component reflects dominance by employment costs and interest payments. In the fiscal year 1996/97, the wage and interest bill accounted for 71 percent of the total revenue, leaving only 29 percent for discretionary expenditures. Interest payments rose from $\mathrm{Z} \$ 1.6$ billion in the $1991 / 95$ fiscal year to $\mathrm{Z} \$ 17$ billion by 1998 .

Table 2: Share of Capital and Recurrent expenditures in GDP

\begin{tabular}{|lccccc|}
\hline$\underline{1996}$ & $\underline{1997}$ & $\underline{1998}$ & $\underline{1999}$ & $\underline{2000}$ \\
Capital Expenditure & $6 \%$ & $4.2 \%$ & $2.2 \%$ & $2.4 \%$ & $4.3 \%$ \\
Recurrent Expenditure 13.6\% & $12 \%$ & $9 \%$ & $11.8 \%$ & $10.2 \%$ \\
\hline
\end{tabular}

Source: National Budget Statements 1995-2002

The ratio of health expenditure as a percent of total Government Expenditure declined from 6.2 percent in 1990/91 to 4.2 percent in 1995/96. This was despite drastic increased pressure for health care due to the HIV/AIDs crisis and the 'health of all by 2000 ' national policy. As a percentage of GDP, health spending declined by half from over 3 percent in 1990 to less than 2 percent in the late 1990s. Health spending per person fell from Z\$58 in 1990/91 fiscal year to Z\$36 in 1995/96 (UNDP/Poverty Reduction Forum, 1999, 9). The cumulative negative effects of these cuts in health spending took the form of increases in user fees, visible drop in outpatient and antenatal attendances at clinics, shortage of drugs, exit of doctors and nurses, congestion at casualty departments and overcrowding at most major referral hospitals in Zimbabwe such as Parirenyatwa, Harare Hospital, Mpilo, Gweru General. Table 2 below presents a summary of health expenditure allocations from 1990 to 1995, the period under which ESAP was in full force. 
Table 2: Expenditure on Health

\begin{tabular}{|l|lr|l|l|}
\hline Financial Year & $\begin{array}{l}\text { Total } \\
\text { Expenditure peal } \\
\text { Capital }\end{array}$ & $\begin{array}{l}\text { Health Expenditure } \\
\text { as \% of GDP }\end{array}$ & $\begin{array}{l}\text { Health Expenditure } \\
\text { as of Total Govt } \\
\text { Expenditure }\end{array}$ \\
\hline $1990 / 91$ & 57.72 & 3.0 & 6.2 \\
\hline $1992 / 93$ & 44.00 & 2.4 & 5.3 \\
\hline $1993 / 94$ & 38.45 & 2.2 & 5.1 \\
\hline $1994 / 95$ & 38.31 & 2.2 & 4.2 \\
\hline $1995 / 96$ & 35.86 & 2.2 & 4.2 \\
\hline
\end{tabular}

Adapted from UNDP, 1999, 9

These expenditure scenarios should be appreciated within the context of a socioeconomic environment characterized by expenditure pressures from AIDS/HIV pandemic, drought-induced imports, punitive interests of above 40 percent, inflationary pressures arising from the fall of the Zimbabwean local currency in 1997, compulsory land acquisitions and inter-party violence, especially after the formation of the Movement of Democratic Change (MDC) in 1999. The period also witnessed general recourse to unbudgeted expenditures in the form of $Z \$ 50000$ gratuities and $Z \$ 2000$ each per month pensions to war veterans as well as state involvement in the Democratic Republic of Congo-expenditure decisions in which both the public and parliament were not consulted. The period also experienced an expansion in state-funded tertiary institutions. It is also instructive to note that while the major thrust of ESAP was to reduce subsidies from the parastatal sector from $\mathrm{Z} \$ 649$ million (3.7 percent of GDP) in 1990 to zero by 1995, parastatals continued to receive allowances in the period under review.

\subsection{The Third Decade (2000-2012):}

\subsubsection{The Environment}

Public expenditure management under during the third was in the main expenditure management under turmoil and duress. It was enforced within a largely unpredictable environment context characterized by social, economic and political meltdown. The political meltdown manifested itself in the form of increased inter-party violence, precipitous decline 
in the value of local currency and liquidity crises, balance of payments problems, liquidity problems and severe shortage of food, fuel, drugs and electricity, among others. These scenarios compromised the impact of efforts directed towards public expenditure management at the macro and micro levels of government.

\subsubsection{Size of government}

The size of the government as reflected by the number of Ministerial Votes continued to increase, expanding from 20 in 2001 to 41 at the formation of the inclusive government in 2009. An increase in the size of government invariably increases the size public expenditures.

\subsubsection{Overall Spending}

Overall government expenditure increased before and after the formation of the inclusive era, that is, before after dollarization in 2009. Increases in aggregate expenditures prior to 2009 were largely a result of the hyper-inflationary environment. Overall aggregate expenditure shot up from $Z \$ 342.5$ billion in 2002 to $Z \$ 770.2$ billion in 2003 , to $Z \$ 6.250$ trillion in 2004 , $\mathrm{Z} \$ 824$ billion in 2006, Z\$4.5 trillion in 2007 and quintillions in 2008. Despite the adoption of a multi-currency exchange framework and subsequent stabilization in inflation coupled with the "we eat what we kill" fiscal management approach-overall expenditure continued to increase in nominal and real terms, rising from US\$1.39 billion in 2009, US\$2.5 billion in 2010 and US\$ 4 billion in 2012 (GoZ Budget Statements, 2009, 2010, 2011 and 2012; www.zimtreasury.org). Expenditures also arose from power generation efforts such as the rehabilitation of the Kariba and Hwange power stations, themal stations in Harare, Bulawayo and Munyati.

\subsubsection{Vote Allocation}

Vote Allocation trends were generally consistent with those of the second decade, ministries of Health and Education dominating Vote Appropriations. This trend remained visible even after the formation of the inclusive government in 2009 where the two ministries of Health and Education accounted for 8.3 percent and 7.9 per cent of the total expenditure of US\$1.9 billion, respectively (www.zb.co.zw). In the 2010 budget, the health ministry and education accounted for 16 and 17 percent, respectively; scenarios that were also manifest in the 2012 budget where ministries of education accounted for 17.64 percent while the ministry of Health accounted for 8.64 percent. In all national budgets of the decade, the Defence Vote remained a serious third place contender, scenarios discernible since the first decade.

\subsubsection{Unbudgeted expenditures}

The period also witnessed an increase in the frequency of unbudgeted expenditures. In 2000, unbudgeted expenditures resulted in a $\mathrm{Z} \$ 35.5$ billion supplementary budget, a budget that was 37 per cent of the original budget. This was despite the introduction of a cash budgeting system in 2001 whereby expenditures were limited to budget resources, with no allowance for unbudgeted expenditures, except in cases of natural disasters. Unbudgeted expenditure 
practices worsened with the onset of the socioeconomic meltdown between 2004 and 2008 where they took the form of quasi fiscal activities by the Reserve Bank of Zimbabwe, financing of the constitution making process and the Referendum, the fast trek land reform programme and the elections of 2002, 2005 and 2008.

\subsubsection{Capital versus Current Expenditures}

The capital expenditure component (allocation for goods and services, operations and maintenance and capital investment) continued to lag behind recurrent expenditure. In the 2001 national budget, capital expenditure constituted 4.6 per cent of total government expenditure while in the 2005 National Budget of $Z \$ 27.5$ trillion, 17 percent ( $Z \$ 5$ trillion) was accounted by capital expenditures. In the 2007 national budget of $Z \$ 4.5$ trillion, capital expenditure accounted for 32.6 percent ( $Z \$ 1.5$ trillion) of total expenditure. This heavy skew towards current expenditures remained manifest in the 2009 National budget of US $\$ 1.39$ billion (following dollarization) where current expenditures accounted for 75 per cent (US $\$ 1.678$ billion) of the total expenditures. In the 2012 national budget of US $\$ 4$ billion, recurrent expenditure accounted for 77.94 percent of the total budget.

\subsubsection{Dominance of the Non-discretional Expenditures}

Equally noticeable was the continued skew of current expenditure towards non-discretional expenditures. In the 2000 fiscal year, non-discretionary expenditures accounted for 69 per cent of aggregate expenditure, the bulk being accounted for by the salary and wage bill. Employment costs mainly arose from the large size of the civil service (235 000) and annual increases awarded to salaries and allowances (GoZ Budget Statement, 2012, 71). However, despite the dominance of the wage and salary bill, civil servants remain the lowest paid. Between 2000 and 2004, the wage bill accounted for about 40 percent of total expenditures. This persisted even after the formation of the inclusive government. In the US\$1.9 billion national budget of 2009, the civil service wage bill accounted for 25.4 per cent of the total expenditure. This dominance was also visible in the 2011 fiscal year where employment costs accounted for 63 per cent of total budget, scenarios that crowded out non-wage expenditure in areas such as infrastructure development and social service delivery. Employment costs are currently pegged around US\$161 million a month.

\subsubsection{Foreign Travel Expenditures}

Foreign travel costs emerged as a visible expenditure sub-head throughout the decade, generally accounting for 2 percent on average in the three budgets of the inclusive government. In 2011, they accounted for 1.2 percent (US\$45.5 million) of the total Budget. Implied by these expenditure allocations is that revenues collected by the state were channeled towards consumption rather than investment, thus hampering infrastructural development.

\subsubsection{Parastatal debts}


Parastatals remained a major drain on the fiscus, incurring huge debts and receiving subventions from the state. In the 2002 fiscal year, government provided a sum of $Z \$ 3.7$ billion to remove inter-parastatal debt. Financial statements by the Ministry of Finance between January and June 2010 for selected key parastatals (Agribank, Air Zimbabwe, CSCL, GMB, NOCZIM, and NRZ) point to a cumulative loss of US\$47 million which ended up being assumed by the fiscus.

\section{Concluding Remarks}

\subsection{Frameworks of Expenditure Management}

Public expenditure management approaches in Zimbabwe generally reflects striking similarities with those in the UK and Anglophone Africa. Ministries of finance, working in close liaison with spending ministries, Accounting Officers, Public Accounts Committees of Parliament, Auditor Generals, internal auditors constitute key players in the public expenditure management process.

Ministries of finance (Treasury) serve as the nerve centre of the public expenditure management process, exercising overall control over the public expenditure process through allocating annual appropriations, issuing out quarterly or annual warrants (treasury instructions) to Accounting Officers who are the Heads of spending ministries.

Accounting Officers in spending ministries act part of the expenditure process by prepare budget projections, ensuring that expenditures remain within authorized limits, endorsing the annual accounts of their ministries as well as defending ministerial budget outturns before Public Accounts Committees of parliament.

Within spending ministries are auditors and accounting officers who assist Accounting Officers in public expenditure management by providing financial records.

Expenditure controls are also exercised through submission of mid-term reports by line ministries to the ministry of finance, though compliance with these requirements has been a major challenge, reports either not received timely or are of poor quality.

While proper public expenditure management demands existence of a single treasury account that is held at the central bank, scenarios suggest existence of parallel accounts, with some operating outside the control of the ministry of finance.

\subsection{Expenditure Management Performance}

Despite the existence of a fairly comprehensive expenditure management framework, expenditure control remained a daunting task throughout the decades, unbudgeted expenditures thwarting the effectiveness of public expenditure management process.

The size of government ministries has been expanding over the years while subsidies to the public enterprise sector remained a major drain on the fiscus. 


\section{Macrothink}

Journal of Public Administration and Governance ISSN 2161-7104 2012, Vol. 2, No. 3

Current expenditures continue to gobble a disproportionate share in aggregate expenditure, non discretionary recurrent expenditures accounting for the bulk.

Efforts towards controlling foreign travel expenditures has remained been a daunting task for throughout the decades. With the formation of the inclusive government, foreign travel related costs have even worsened generally accounting for 2 percent on average in the three budgets of the inclusive government.

\section{Recommendations}

There is need to ensure that the ministry of finance exercises full control over all national revenue and expenditure processes. The ministry of finance should also be empowered to ensure that line ministries make timely submissions of quarterly and yearly reports.

The national leadership needs to buttress the public expenditure control drive by cutting down on foreign travel costs. This should be buttressed by cutting the number of government ministries. This could be done by merging several ministries identified in the text. Such high profile expenditure restraint will go a long way in reinforcing a culture of zero tolerance to excess expenditures.

Measures should also be put in place to ensure that all transactions by line ministries are readily accessible to the ministry of finance.

\section{References}

1. Adam, S (1937) Wealth of Nations (New York: Modern Library)

2. AFRODAD (2011) What has tax got to do with development?(Harare: AFRODAD)

3. Agere, S (1993) "The Strategic and Policy Options for the Management of Redundancies following Retrenchment in the Civil Service in Zimbabwe", Administrative and Managerial Reform in Government (Kuala Lumpur: Commonwealth Secretariat).

4. Peters, B, G \& Savoie, D, J (1994) "Civil Service Reform: Misdiagnosing the Patient", Administrative Review, Vol 54, No 5, pp 418-424.

5. Aronson, R.J (1985) Public Finance (New York: McGraw Hill)

6. Aschauer, D.A (1989) "Is Public Expenditure Productive?", Journal of Monetary Economcs, 23, 177-200

7. Asian Development Bank Institute (2000) "Public Expenditure Management", Asian Development Bank Institute Executive Survey Series (Tokyo: ADBI)

8. Auld, D. and Miller, F (1984) Principles of Public Finance (Toronto: Methuen). 


\section{Macrothink}

Journal of Public Administration and Governance ISSN 2161-7104 2012, Vol. 2, No. 3

9. Bahram, D \& Frank, M (1998) "Does Government Public Capital Expenditure Matter?: Evidence from Canada", Economic Analysis and Policy,Vol.28, No.2

10. Bailey, S, and J (1995) Public Sector Economics: Theory and Practice (London: McMillan).

11. Beck, M (1981) Government Spending: Trends and Issues (New York: Praeger).

12. Blondal, G (2003) Balancing the Budget: Budgeting Practices and Fiscal Policy (Singapore: Harper Collins)

13. Bond, P (1998) Uneven Zimbabwe (Eritrea: Africa World Press)

14. Buchanan, J (1975) Public Finances: An Introductory (Illinois: Textbook Irwin).

15. Buchanan, J (1998) Public Principles of Public Debt (London: Mc Graw Hill)

16. Chosvo, M (1993) Government Spending on Social Services and the Impact of Structural Adjustment in Zimbabwe, Report produced for UNICEF Zimbabwe, Harare, September

17. Colander, D, C (2004) Macroeconomics (Boston: McGraw Hill)

18. Dalton (1970) Principles of Public Finance (London: Rutledge \& Kegan Paul).

19. Diamond, L. (1975) Public Expenditure in Practice (London: Allen and Unwin Ltd)

20. Eshaq, E (1983) Fiscal and Monetary Policies and Problems in Developing Countries (London: Cambridge University Press)

21. Fischer, S (2002) Methods of Public Financial Management (London: University of London)

22. Fjeldstad, O-H and Moore, M (2008) Revenue Authorities and State Capacity in Anglophone Africa (Bergen: CMI) www.cmi.no

23. Fox, W.F \& Meyer, I, H (1995) Public Administration Dictionary(Stellenbosch: Juta $\&$ Co Ltd)

24. Groves, H. M (1955) Financing Government (New York: Holt and Company).

25. Hassa, S \& Jajri, I (2011) “ The Impact of Public Capital Expenditure on the Performance of the private capital expenditure in selected economic sectors in Malaysia, Society of Interdisciplinary Business Research, available http://ssrn.com/abstract

26. Hayman, D (1990) Public Finance (Washington: Dryden Press). 


\section{Macrothink}

Journal of Public Administration and Governance ISSN 2161-7104 2012, Vol. 2, No. 3

27. Honoham, P (2003) Taxation Theory and Practice (London: Oxford University Press).

28. IMF (2002) "Action to Strengthen the Trailing of Poverty-Reduction Public Spending in HIPCs", 22Mrach 2002, www.imf.org

29. IMF (2009) Occasional Papers No.10 (Washington D.C: IMF).

30. IMF (2011) Revenue Mobilization in Developing Countries (Washington: IMF)

31. Ishikawa, S (2006) "The Poverty Trap and Public Expenditure Management: In Pursuit of a New Development Model Discussion Paper on Development Assistance No. 2 (Tokyo: FASID) http:// dakis.facid.or.jp/report/pdf/DP

32. Levine, C, H \& Rubin, I (1980) Fiscal Stress and Public Policy (London: Sage Publications.

33. Loewenson, R and Chisvo, M (1994) Transforming Social Developments: The experience of Zimbabwe, UNICEF

34. Looney, R,E (1980) “ Socio-Economic Budgetary Constraints in Developing Countries: The Effect of Alternative Political Regimes", The Journal of Social, Political and Economic Studies, Vol.13, No.2., available http://ideas.repec.org/a/eap/articl

35. Mikesell, J.L (2011) Fiscal Administration: Analysis and Applications for the public sector (Boston: Wadsworth Publishing Company)

36. Mlambo A.S (1997) The Economic Structural Adjustment Program: The case of Zimbabwe, 1990-95 Harare: University of Zimbabwe Publications.

37. Moyo, J, (1992) Politics of the National Purse: Public Budgeting as Public Policy, Harare: SAPES.

38. Mumbengegwi, C (1987) "Continuity and Change in Agricultural Policy" in Mandaza, I (ed) Zimbabwe: The Political Economy of Transition 1980-1986 (Senegal: Codeseria).

39. Musgrave, R, A and Musgrave, P, B (1984) Public Finance in Theory and Practice (Tokyo: McGraw Hill)

40. Nigro, F, A and Nigro, L.G (1984) Modern Public Administration (New York: Harper and Row)

41. Odedun, M.O (1997) "Relative effects of public versus private investment spending on economic efficiency and growth in developing countries", Applied Economics, 29, $1325-1336$. 
42. OECD (2001) Managing Public Expenditure: A Reference Book for Transition Countries, Paris.

43. OECD (2003) "A Comparison Between Two Public Expenditure Management Systems in Africa", Volume 3, No 3 www.oced.org

44. OECD(1998) Public Expenditure Management Improvement in the Philippines: Efforts Initiated and Envisioned Reforms, CCNM/EMEF/PUMA/RD (98)4 www.oecd.org/dataoecd

45. Pigou, A. C (1982) A Study in Public Finance (London: Mc Milan Press).

46. Potter, B, H \& Diamond, J (1999) Guidelines for Public Expenditure Management (New York: IMF)

47. Potter, B.H \& Diamond, J (1999) Guidelines for Public Expenditure Management (New York : IMF)

48. Poverty Reduction Forum (1999) Towards a pro-poor national Budget: Recommendations for the 1999 National Budget (Harare: IDS)

49. Poverty Reduction Forum (2003) Reforming the National Budget: Lessons from the 1980-2002(UNDP-IDS, Harare)

50. Prest, A. R (1962) Public Finance in Theory and Practice (Tokyo: Mc Graw Hill).

51. Reynolds, L, G (1985) Macroeconomics: Analysis and Policy (Illinois: Irwin Press)

52. Roberts, J (2003) "Managing Public Expenditure for Development Results and Poverty Reduction" Overseas Development Institute Working Paper 2003 www.odi.org.uk/publications/brifings/

53. Rukuni, M \& Eicher, C, L (1994) Zimbabwe's Agricultural Revolution (Harare: University of Zimbabwe Publications)

54. Schiller, B, R (2003) The Economy Today (Boston: McGraw Hill)

55. Seidman, A. (1986) Money, Banking and Public Finance in Africa (London: Zed Books).

56. Shaw, A (2005) Fiscal Management (Washington: World Bank)

57. Sheffrin, S.M and Sullivan, A (2003) Economics: Principles in action (New Jersey: Upper Saddle River)

58. Tait A. and Heller, P.S. (1982) "International Comparison of Government Expenditure” IMF Occasional Papers, No.10, (Washington D.C.: IMF). 
59. Tobin, James (1980) "Military Expenditure and Investment in OECD Countries", Journal of Economics 4, No.1, 19-32.

60. Tresch R.W (1985) Public Finance: Normative Theory (London: Weidenfield)

61. UNDP (1998) Human Development Report Zimbabwe (Institute of Development Studies, Harare).

62. Visser C, B and Erasmus, P W (2005) The Management of Public Finance: A Practical Guide (Oxford: Oxford University Press)

63. Wagner, A (1958) "Three Extracts on Public Finance" in Richard A. Musgrave and Allan Peacock(eds), Classics in the Theory of Public Finance, New York: Macmillan, pp.1-16.

64. Wildavsky, A (1986) Budgeting: A comparative Theory of the Budgetary Process (Boston, Little, Brown and Company)

65. Wilson, J. (1998) Financial Management in the Public Sector (Birmingham: Open University Press)

66. Woods, T.E (2011) Rollback : Repealing the Government before final collapse( New York: Regenery Publishing) available http://www.theamercanconservative.com/articles

67. World Bank (1998) Public Expenditure Management Handbook, Washington

68. Zhou, G (2011) "Fiscal Management in Zimbabwe", International Journal of Economic and Modeling, Vol.3, Issue 1, pp 152-161.

69. ZIMCODD (2001) The Social Effects and Politics of Public Debt in Zimbabwe: Impact of Public Debt Management on Development (Harare: Strand Multiprint Pvt Ltd)

70. Zvobgo, R (1987) "Education and the Challenge of Independence" in Zimbabwe: The Political Economy of Transition 1980-1986( Senegal: Codeseria)

\section{Newspaper Articles}

1. Financial Gazette, October 8, 2009

2. Herald, 16 June 2010.

3. Zimbabwe Independent, 23-29 July, 2010, p: 12-15

4. NewsDay, 22 July, 2011, pp: 1-2 
5. Financial Gazette, 21-27 July, 2011, p: 5.

6. Financial Gazette, 21-27 July, 2011 p: C2-C3

7. Sunday Mail, 31 July, 2011 p: 1 and 4)

8. Zimbabwe Independent 29 July-4 August, 2011, pp: 7-8.

9. The Financial Gazette, 4-10, 2011, August, p: C5

\section{Government Publications}

1. Government of Zimbabwe (1981) Growth with Equity: An Economic Policy Statement, Ministry of Finance, Economic Planning and Development, Government Printer, Harare.

2. Government of Zimbabwe (1991) Framework for Economic Reform, 1991-95, Government Printer, Harare.

3. Government of Zimbabwe (1994) Reserve Bank of Zimbabwe Chapter 22:15, Harare, Jongwe Printers and Publishing Co.

4. Government of Zimbabwe (1996) Audit and Exchequer Act Chapter 22:03, Jongwe Printers

5. Government of Zimbabwe (1998) Budget Statement, Harare, Printflow

6. Government of Zimbabwe (1998) National Budget Statement, Harare, Government Printers

7. Government of Zimbabwe (2004) Monetary Policy Statement, Harare, RBZ

8. Government of Zimbabwe (2004) Parliamentary Debates, Volume 31, No.8, 13 October, Harare, Jongwe Printing and Publishing Co

9. Government of Zimbabwe (2004) Report on the 2004 Budget Statement, SC 30, Harare, Government Printers

10. Government of Zimbabwe (2005) Budget Statement, Harare, Printflow

11. Government of Zimbabwe (2006) Budget Statement, Harare, Printflow

12. Government of Zimbabwe (2006) Comptroller and Auditor General Report, Harare, Printflow

13. Government of Zimbabwe (2006) Monetary Policy Statement, Harare, RBZ 
14. Government of Zimbabwe (2008) Comptroller and Auditor General Report, Harare, Printflow

15. Government of Zimbabwe (2008) Government Political Agreement, Harare, Printflow

16. Government of Zimbabwe (2008) Monetary Policy Statement, Harare, Printflow17.

17. Government of Zimbabwe (2009) Budget Statement, Harare, Printflow

18. Government of Zimbabwe (2009) Central Statistical Office, Harare, Printflow

19. Government of Zimbabwe (2010) Audit Office Act, Harare, Printflow

20. Government of Zimbabwe (2010) Audit Office Act, Harare, Printflow

21. Government of Zimbabwe (2010) Budget Statement, Harare, Printflow

22. Government of Zimbabwe (2010) Central Statistical Office, Harare, Printflow

23. Government of Zimbabwe (2010) Public Finance Management Act, Chapter 22:19, Harare, Printflow

24. Government of Zimbabwe (2011) Budget Statement, Harare, Printflow

25. Government of Zimbabwe (2011) Medium Term Plan, 2011-2015, Harare, Printflow

26. Government of Zimbabwe (2012) Budget Statement, Harare, Printflow

27. Government of Zimbabwe (2006) Monetary Policy Statement, Harare, Printflow

28. Government of Zimbabwe: Constitution of Zimbabwe, Harare, Government Printers

29. Government of Zimbabwe: Finance Act (Chapter 23:05), Harare, Printflow

30. Government of Zimbabwe: Incomes Tax Act (Chapter 23:06), Harare, Government Printers.

31. Government of Zimbabwe: State Loans and Guarantees Act (Chapter 22:13), Harare, Government Printers

\section{Internet Sources}

1. www.//blog-pfm.imf.org/pfmblog/2009/10

2. www.britannica.com

3. www.adbi.org/executive-summary/2004/07/27/464public.expenditure. management/ 
4. www.finance.gov.za

5. www.finance.za

6. www.zimtreasury.org

7. www.sokwanele.com

8. www.oecd.org

\section{Copyright Disclaimer}

Copyright reserved by the author(s).

This article is an open-access article distributed under the terms and conditions of the Creative Commons Attribution license (http://creativecommons.org/licenses/by/3.0/). 